\title{
Type B Spindle Cell Melanoma
}

National Cancer Institute

\section{Source}

National Cancer Institute. Type B Spindle Cell Melanoma. NCI Thesaurus. Code C4239.

A melanoma characterized by the presence of malignant spindle-shaped melanocytes with larger nuclei and distinct nucleoli. Representative example is the type B spindle cell uveal melanoma. 